\title{
B7h-expressing dendritic cells and plasma B cells mediate distinct outcomes of ICOS costimulation in T cell-dependent antibody responses
}

\author{
Kevin Larimore, Linda Liang, Sonia Bakkour and William C Sha
}

\begin{abstract}
Background: The ICOS-B7h costimulatory receptor-ligand pair is required for germinal center formation, the production of isotype-switched antibodies, and antibody affinity maturation in response to $T$ cell-dependent antigens. However, the potentially distinct roles of regulated B7h expression on B cells and dendritic cells in $T$ cell-dependent antibody responses have not been defined.
\end{abstract}

Results: We generated transgenic mice with lineage-restricted B7h expression to assess the cell-type specific roles of B7h expression on B cells and dendritic cells in regulating $T$ cell-dependent antibody responses. Our results show that endogenous B7h expression is reduced on B cells after activation in vitro and is also reduced in vivo on antibody-secreting plasma $B$ cells in comparison to both naïve and germinal center B cells from which they are derived. Increasing the level of B7h expression on activated and plasma B cells in B-B7hTg mice led to an increase in the number of antibody-secreting plasma cells generated after immunization and a corresponding increase in the concentration of antigen-specific high affinity serum lgG antibodies of all isotypes, without affecting the number of responding germinal center B cells. In contrast, ICOS costimulation mediated by dendritic cells in DC-B7hTg mice contributed to germinal center formation and selectively increased lgG2a production without affecting the overall magnitude of antibody responses.

Conclusions: Using transgenic mice with lineage-restricted B7h expression, we have revealed distinct roles of ICOS costimulation mediated by dendritic cells and B cells in the regulation of T cell-dependent antibody responses.

Keywords: ICOS, B7h, Costimulation, Antibody, Germinal center, Plasma cell, Dendritic cell

\section{Background}

ICOS is an inducible costimulatory receptor expressed on activated $\mathrm{T}$ cells that is a member of the CD28-B7 family of costimulatory molecules [1-4]. ICOS binds to the ligand B7h [5] (also known as LICOS [6], ICOSL [7], GL50 [8], B7RP-1 [9], and B7-H2 [10]), expressed constitutively on the cell surface of resting $B$ cells and dendritic cells (DCs) $[5,9,11,12]$, both of which can regulate T celldependent antibody responses. Studies of $\mathrm{B}^{-1-} \mathrm{h}^{-1}$ and $\mathrm{ICOS}^{-1-}$ mice have demonstrated the requirement of the ICOS-B7h receptor-ligand pair in germinal center

\footnotetext{
* Correspondence: kevinlarimore@gmail.com

Immunology Division, Department of Molecular and Cell Biology, University of California, Berkeley, CA 94720-3200 USA
}

formation, class switched antibody production and antibody affinity maturation [7,13-15], but the potentially distinct roles of ICOS costimulation mediated by B7hexpressing B cells and DCs in the regulation of antibody responses have not been well defined.

ICOS signaling can promote IL-4 production, leading to Th2 polarization of differentiating CD4+ $\mathrm{T}$ cells $[16,17]$, but can also enhance production of a variety of cytokines in other Th subsets that have already differentiated, including augmentation of IFN- $\gamma$ production in Th1 cells [18-20]. Thus, ICOS signaling in T cells can have different effects on immune responses depending upon the cellular context of ICOS-B7h interactions. In $\mathrm{T}$ cell-dependent antibody responses, ICOS-expressing 
activated CD4+ $\mathrm{T}$ cells can make contact with B7hexpressing antigen presenting cells in several distinct contexts, with the potential for regulation of different aspects of the response through ICOS signaling during each interaction. DCs can contact recently-activated CD4+ ICOS + T cells in T cell zones [21], and DCs in germinal centers can interact with ICOS + Tfh cells [22]. Recently activated $\mathrm{B}$ cells interact with cognate activated CD4+ T cells at the border of the T cell and B cell zones in lymph nodes and spleen prior to germinal center and plasma cell formation [22], germinal center B cells interact with ICOS + follicular helper $\mathrm{T}$ (Tfh) cells [23], and antibody-secreting plasma B cells interact with activated Th cells in periarteriolar lymphoid sheaths [24]. Because the outcome of ICOS signaling in CD4+ T cells depends upon the differentiation and programming of $\mathrm{T}$ cells in each context [25], these interactions represent potentially distinct points of control for antibody responses, where modulation of ICOS signaling by regulated $\mathrm{B} 7 \mathrm{~h}$ expression on antigen presenting cells could have different effects.

Previous in vitro studies have shown that downregulation of $\mathrm{B} 7 \mathrm{~h}$ expression on $\mathrm{B}$ cells after activation can restrict ICOS costimulation in cognate CD4+ T cells, suggesting that regulation of $\mathrm{B} 7 \mathrm{~h}$ levels on activated $\mathrm{B}$ cells in vivo could be a control mechanism in $\mathrm{T}$ celldependent antibody responses. B7h expression on activated $B$ cells is transcriptionally extinguished by exposure to antigen and IL-4 [26], and is also limited by rapid ectodomain shedding induced either by binding to ICOS or by antigen receptor signaling [27]. Conversely, B7h expression can be restored by the reactivation of transcription induced by CD40 signaling [26], and enhanced by the inhibition of ectodomain shedding induced by TLR7/8 and TLR9 signaling [27]. Thus, the level of B7h expression on activated $B$ cells reflects the integration of multiple critical B cell signaling pathways.

To investigate the cell type-specific functions of regulated B7h expression on B cells and DCs in vivo, we generated transgenic mice with lineage-restricted $\mathrm{B} 7 \mathrm{~h}$ expression. Our results show that ICOS costimulation mediated by DCs contributes to germinal center formation in response to $\mathrm{T}$ cell-dependent antigens and leads to a selective increase in antibody class switching to the IgG2a isotype, without affecting the overall magnitude of antibody responses. In contrast, increased expression of B7h on B cells, but not on dendritic cells, markedly enhances both the number of plasma cells secreting antigen-specific high affinity class-switched antibodies and the serum concentration of such antibodies, without affecting the number of germinal center $B$ cells or antibody isotype usage. Thus, we have defined distinct roles of ICOS costimulation mediated by DCs and plasma B cells in $\mathrm{T}$ cell-dependent antibody responses.

\section{Results}

\section{DC-B7hTg mice overexpress B7h on CD11C +} dendritic cells

To investigate the in vivo roles of B7h expression on dendritic cells and $\mathrm{B}$ cells, both of which can regulate $\mathrm{T}$ cell-dependent antibody responses, we generated transgenic mice with lineage-restricted $B 7 h$ expression. We targeted the expression of B7h to DCs using a transgenic expression vector driven by the CD11c promoter [28]. The DC-B7hTg line was selected from founder mice based on overexpression of B7h on CD11c + cells, and dendritic cell-specific transgene expression was confirmed by analyzing DC-B7hTg mice on the $\mathrm{B} 7 \mathrm{~h}^{-/-}$background to avoid any contribution from endogenous $\mathrm{B} 7 \mathrm{~h}$ (Figure 1A). Flow cytometric analysis revealed that $\mathrm{B} 7 \mathrm{~h}$ transgene expression in DC-B7hTg mice was restricted to $\mathrm{CD} 11 \mathrm{c}+\mathrm{DCs}$, and was not expressed on either resting or in vitro-activated B or T cells. Expression of the DCB7h transgene was significantly higher than endogenous B7h on both resting and activated DCs (Figure 1B), indicating that the DC-B7hTg line could be used to study the potential regulatory role of enhanced $B 7 \mathrm{~h}$ expression on dendritic cells in vivo.

\section{The B-B7h transgene drives B7h expression on activated $B$ cells}

Expression of B7h was also targeted to B cells using a transgenic expression vector driven by an immunoglobulin heavy chain $\mathrm{VH}$ promoter and the intronic E $\mu$ enhancer [29]. Since BCR cross-linking induces substantial down-regulation of endogenous B7h on B cells [26], we selected the B-B7hTg line from founder mice based on enhanced B7h expression on anti-IgM-activated B cells. To confirm B cell-specific transgene expression, we analyzed B7h expression on splenocytes from B-B7hTg mice on the $\mathrm{B}^{-1-} \mathrm{h}^{-1}$ background to avoid any contribution from endogenous B7h (Figure 1A). Although transgene expression was restricted to $\mathrm{B} 220+$ cells, and was not expressed on either dendritic cells or resting or activated $\mathrm{T}$ cells, transgene expression on naïve B cells was very low. Significant transgenic B7h expression, approaching the level of endogenous B7h on naïve wild-type B cells, required extended in vitro $B$ cell activation with antiIgM antibodies (Figure 1A: $16 \mathrm{hr}$ stimulation; Figure $1 \mathrm{C}$ : 3 day stimulation). Thus, the B7h transgene in B-B7hTg mice was restricted to $B$ cells and was induced after activation.

The essentially wild-type levels of $\mathrm{B} 7 \mathrm{~h}$ on naive $\mathrm{B}$ B7hTg B cells on the $\mathrm{B}^{\mathrm{h}} \mathrm{h}^{+/+}$background allowed us to focus specifically on testing the in vivo significance of endogenous B7h down-regulation on activated B cells. A prior study attempting to analyze the reciprocal question of the in vivo significance of B7.2 induction on activated B cells employed the analogous approach of generating 


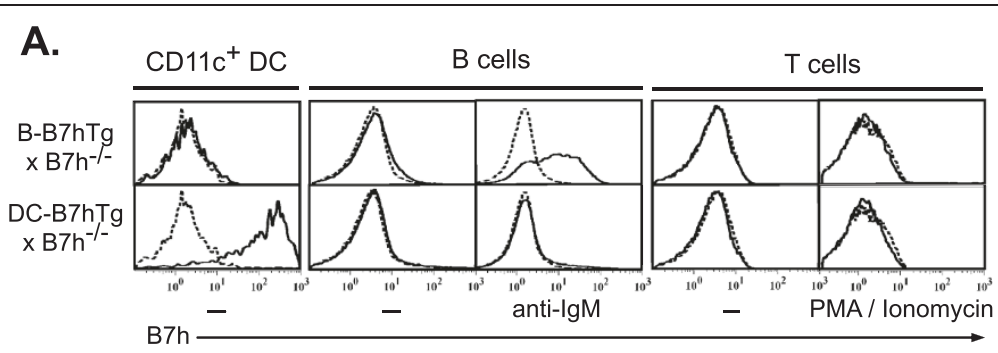

B.

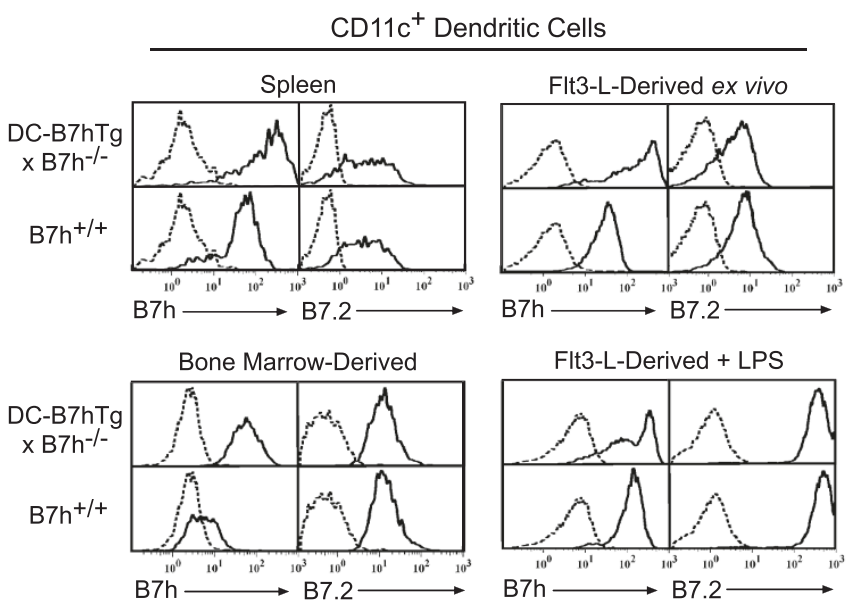

C.

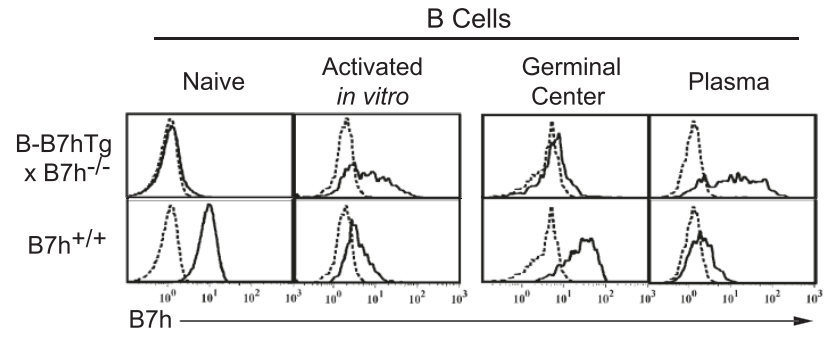

Figure 1 Lineage-specific B7h transgene expression on B cells from B-B7hTg mice after activation and on dendritic cells from DC-B7hTg mice. B7h transgene expression in B-B7hTg and DC-B7hTg mice was assessed by flow cytometry on the B7h ${ }^{-/-}$background to avoid contribution from endogenous B7h. B7h staining is shown (solid line) after gating on the indicated cell subsets, with background staining of

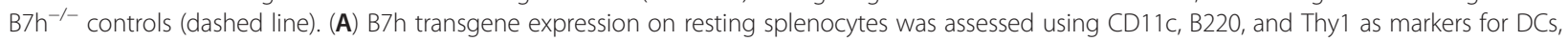
$B$ cells and T cells, respectively. To assess transgene expression on activated B and T cells, purified resting splenic B and T cells were activated for 16 hours with anti-lgM F(ab') $)_{2}$ or PMA and ionomycin, respectively. (B) B7h and B7.2 expression were examined on splenic CD11c+ dendritic cells from naive mice, purified CD11c+ dendritic cells derived from bone marrow, and splenic CD11c+ cells purified from mice injected with Flt3-ligand-expressing B16 cells, either directly ex vivo or after 16 hours of treatment with LPS. For B7.2 analysis, dashed lines represent the background staining of a non-specific isotype control antibody. (C) B7h staining of purified resting splenic B cells, gated B220 $0^{+}$, was assessed

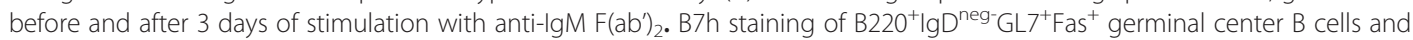
$\lg \mathrm{D}^{\text {neg- }}$ syndecan- $1^{+} B 220^{\text {lo }}$ plasma B cells was assessed at day 7 in mice immunized with NP-CGG in alum.

transgenic mice expressing a B cell-specific B7.2 transgene [30]. Interpretation of antibody responses in these mice, however, was precluded by a severe reduction in the number of resting naive $B$ cells that resulted from the inappropriate expression of B7.2 on resting B cells. In contrast, both B-B7hTg mice, with restricted $\mathrm{B} 7 \mathrm{~h}$ transgene expression on activated B cells, and DCB7hTg mice, with restricted B7h transgene expression on CD11c+ DCs, exhibited normal numbers of B220+, CD4+, $\mathrm{CD} 8+$, and $\mathrm{CD} 11 \mathrm{c}+$ splenocytes (Additional file 1:
Figure S1), consistent with phenotypically normal resting immune systems.

\section{Endogenous B7h expression is limited on plasma B cells}

Although it was known that B cell receptor and IL-4R activation of B cells led to extinguishment of B7h expression in vitro [26], the corresponding in vivo expression of B7h on activated germinal center and plasma B cell subsets was not known at the time we began our studies. In wild-type C57Bl6 mice immunized with the T 
cell-dependent antigen NP-CGG (4-Hydroxy-3-nitrophenylacetyl hapten conjugated to chicken gamma globulin)in alum, B7h was highly expressed on $\mathrm{B}^{2} 20^{+} \mathrm{IgD}^{+}$naïve $\mathrm{B}$ cells and $\mathrm{B}^{2} 20^{+} \mathrm{IgD}^{\text {neg }} \mathrm{GL}^{+} \mathrm{Fas}^{+}$germinal center $\mathrm{B}$ cells, but the expression level was dramatically reduced on IgD ${ }^{\text {neg }}$ Syndecan $-1^{+}$B220 ${ }^{\text {lo }}$ plasma B cells (Figure $1 \mathrm{C}$ ). In contrast, transgene-driven $\mathrm{B} 7 \mathrm{~h}$ expression in immunized $\mathrm{B}-\mathrm{B} 7 \mathrm{hTg}$ mice on the $\mathrm{B} \mathrm{h}^{-1-}$ background was barely detectable on naïve and germinal center B cells, but appeared to be selectively induced on responding plasma B cells.

\section{The B-B7h transgene drives overexpression of B7h on activated and plasma $B$ cells in the presence of endogenous $B 7 h$}

Having observed induction of $\mathrm{B} 7 \mathrm{~h}$ expression on $\mathrm{B}$ cells from B-B7hTg mice on the $\mathrm{B}^{-1} \mathrm{~h}^{-1}$ background after in vitro activation or in vivo differentiation to the plasma cell lineage, and reduction of $\mathrm{B} 7 \mathrm{~h}$ expression on WT B cells under the same conditions, we sought to determine whether the presence of the B-B7h transgene would lead to overexpression of $\mathrm{B} 7 \mathrm{~h}$ on activated and plasma B cells in the presence of endogenous B7h. To assess B7h expression on activated B cells, we purified $\mathrm{B}$ cells from naïve $\mathrm{B} 7 \mathrm{~h}^{-1-}, \mathrm{B} 7 \mathrm{~h}^{+/-}$, and $\mathrm{B}-\mathrm{B} 7 \mathrm{hTg}$ mice on the $\mathrm{B} \mathrm{h}^{-/-}$and $\mathrm{B} 7 \mathrm{~h}^{+/-}$backgrounds, cultured the cells for 72 hours in the presence of B cell stimuli, and measured cell-surface B7h expression by FACS (Figure 2A). Endogenous B7h expression was high on untreated B cells and was reduced after culture with an activating anti-IgM antibody $\left.\mathrm{F}(\mathrm{ab})_{2}\right)_{2}$, LPS, IL-4, or CpG oligonucleotide, consistent with previous observations [26]. Conversely, on the $\mathrm{B}^{-1-} \mathrm{h}^{-/}$background the B-B7h transgene was not expressed on untreated cells, was strongly induced by IgM cross-linking, and was induced at a low level by culture with LPS or CpG DNA, but not IL-4. B cells from B-B7hTg mice on the $B 7 \mathrm{~h}^{+/-}$background expressed $\mathrm{B} 7 \mathrm{~h}$ on the cell surface at levels equivalent to non-transgenic controls directly ex vivo, and activating stimuli led to down-regulation of $\mathrm{B} 7 \mathrm{~h}$ expression after culture in vitro. However, the level of cell-surface B7h after IgM cross-linking was markedly higher on cells from B-B7hTg mice on the

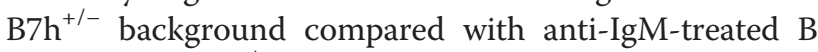
cells from $\mathrm{B} \mathrm{h}^{+/-}$mice, suggesting that induction of transgenic $\mathrm{B} 7 \mathrm{~h}$ expression led to overexpression of $\mathrm{B} 7 \mathrm{~h}$ on B cells after BCR-mediated activation, when endogenous B7h expression was limited.

To determine whether the $\mathrm{B}-\mathrm{B} 7 \mathrm{~h}$ transgene led to overexpression of $\mathrm{B} 7 \mathrm{~h}$ on plasma $\mathrm{B}$ cells in the presence of endogenous $\mathrm{B} 7 \mathrm{~h}$ in vivo, we isolated splenocytes from $\mathrm{B} 7 \mathrm{~h}^{-1-}$ and $\mathrm{B} 7 \mathrm{~h}^{+/-}$mice, as well as $\mathrm{B}-\mathrm{B} 7 \mathrm{hTg}$ mice on the $\mathrm{B} \mathrm{h}^{-1-}$ and $\mathrm{B} 7 \mathrm{~h}^{+/-}$backgrounds, 7 days after immunization with NP-CGG, and analyzed B7h expression on $\mathrm{B}$ cell subsets by FACS (Figure 2B). On both $\mathrm{B} 220^{+} \mathrm{IgD}^{+}$naïve $\mathrm{B}$ cells and $\mathrm{B} 220^{+} \mathrm{IgD}^{\text {neg }} \mathrm{GL}^{+} \mathrm{CD} 95^{+}$ germinal center $\mathrm{B}$ cells, B7h expression was equivalently high on cells from $\mathrm{B} \mathrm{h}^{+/-}$mice and B-B7hTg mice on the $\mathrm{B} \mathrm{h}^{+/-}$background, and barely detectable on cells from $\mathrm{B}-$ B7hTg mice on the $\mathrm{B}^{-1} \mathrm{~h}^{-1}$ background, indicating that the $\mathrm{B}-\mathrm{B} 7 \mathrm{~h}$ transgene did not induce $\mathrm{B} 7 \mathrm{~h}$ expression in these subsets. In contrast, $\operatorname{IgD}^{\text {neg }} \mathrm{B} 220^{\mathrm{lo}} \mathrm{CD} 138^{+}$plasma $\mathrm{B}$ cells from $\mathrm{B} 7 \mathrm{~h}^{+/-}$mice expressed low levels of cell surface B7h, while B-B7hTg mice on both the $B 7 \mathrm{~h}^{+/-}$ and $\mathrm{B}^{-1} \mathrm{~h}^{-1-}$ backgrounds expressed high levels of $\mathrm{B} 7 \mathrm{~h}$, confirming that the B-B7h transgene was induced on plasma B cells, leading to overexpression in the presence of endogenous $\mathrm{B} 7 \mathrm{~h}$. These results suggest that ICOS costimulation might normally be limited by down-regulation of endogenous $\mathrm{B} 7 \mathrm{~h}$ expression on recently-activated $B$ cells and differentiated plasma $B$ cells, and the observed induction of B7h on activated and plasma B cells in B-B7hTg mice could be used to test the functional significance of regulated $\mathrm{B} 7 \mathrm{~h}$ expression on wild-type B cells in vivo.

\section{B7h expression on B cells regulates the magnitude of $T$ cell-dependent antibody responses}

B-B7hTg mice and non-transgenic littermates on the $\mathrm{B} \mathrm{h}^{+/+}$background were immunized with the $\mathrm{T}$ celldependent antigen NP-CGG in alum, and anti-NP serum antibody concentrations were measured after 7 days by ELISA (Figure 3A). Total anti-NP IgG, but not anti-NP IgM responses were significantly increased in B-B7hTg mice over non-transgenic littermate controls. The increase in total anti-NP IgG responses of B-B7hTg mice was reflected in all IgG isotypes examined, suggesting that the level of $B 7 \mathrm{~h}$ expression on responding plasma $\mathrm{B}$ cells regulated the overall magnitude of the IgG response through ICOS costimulation. Investigation of serum antibody responses on day 14 after immunization (Figure 3C) confirmed the increase in antigen-specific antibody concentration in B-B7hTg mice over controls, while the IgG2a/IgG1 isotype ratio was equivalent to that seen in wild-type mice, suggesting that plasma $B$ cell-mediated ICOS signaling did not affect antibody isotype usage.

We observed increased production of anti-NP IgG1 antibodies (as well as other IgG isotypes not shown) from overnight cultures of splenocytes isolated from $\mathrm{B}-\mathrm{B} 7 \mathrm{hTg}$ mice on the $\mathrm{B} 7 \mathrm{~h}^{+/+}$background 7 days after immunization, compared with wild-type controls (Figure 4A). To determine whether this phenotype resulted from increased plasma cell numbers or from increased antibody production per plasma cell, we measured the number of NP-specific IgG1-secreting splenocytes by ELISPOT analysis. Increased numbers of anti-NP antibody-producing 


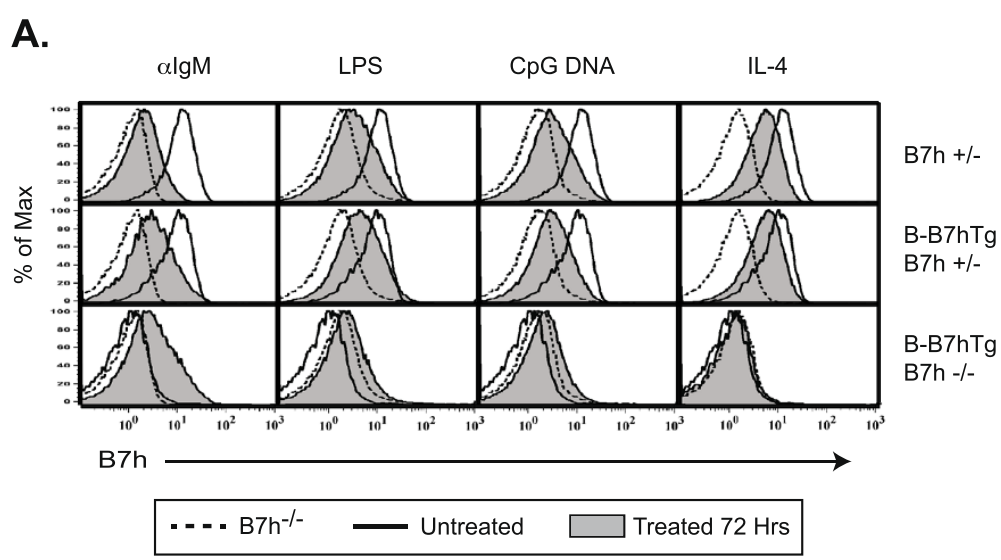

B.
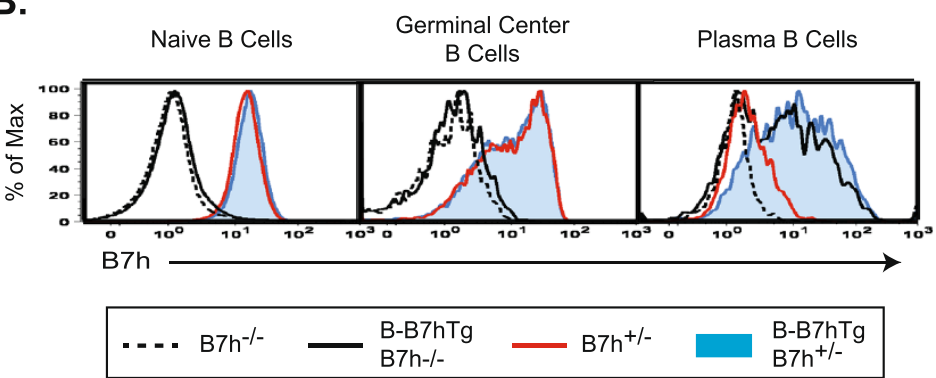

Figure 2 The B-B7h transgene is overexpressed on activated and plasma B cells in the presence of endogenous B7h. (A) Purified B cells from $\mathrm{B} 7 \mathrm{~h}^{+/-}, \mathrm{B} 7 \mathrm{~h}^{-/-}$, and $\mathrm{B}-\mathrm{B} 7 \mathrm{hTg}$ mice on the $\mathrm{B} 7 \mathrm{~h}^{+--}$and $\mathrm{B} 7 \mathrm{~h}^{-/-}$backgrounds were cultured for 72 hours in the presence of activating stimuli, and cell surface B7h levels were measured by FACS. Dashed lines represent staining of B7h on B $7 \mathrm{~h}^{-1-}$ cells cultured in the presence of stimuli; solid lines represent cells cultured without stimuli, and shaded histograms represent cells cultured with stimuli, from mice of the genotypes shown on the right. (B) Seven days after immunization with NP-CGG, splenocytes from mice with the genotypes indicated in the legend were analyzed by FACS for cell-surface B7h levels and lineage markers. Naîve B cells were gated B220 ${ }^{+} \mathrm{gD}^{+}$, germinal center B cells were gated B220 ${ }^{+} \operatorname{IgD}{ }^{\text {neg }} \mathrm{GL}^{+} \mathrm{CD}^{+} 5^{+}$, and plasma cells were gated $\operatorname{lgD}{ }^{\text {neg }} \mathrm{B} 220^{\text {lo }} \mathrm{CD} 138^{+}$.

cells were observed in splenocytes from B-B7hTg mice, but not from DC-B7hTg mice, when compared to wild-type controls (Figure 4B). Increased plasma cell numbers in immunized B-B7hTg mice did not result from an increase in the number of germinal center $B$ cells that can give rise to antibodysecreting plasma cells [31], as equivalent numbers of germinal center $\mathrm{B}$ cells were detected by flow cytometry at the peak of the germinal center response in spleens from both immunized B-B7hTg and DCB7hTg mice on the $\mathrm{B} \mathrm{h}^{+/+}$background, in comparison to wild-type controls (Figure 4C). These results suggest that the number of plasma cells generated in response to $\mathrm{T}$ cell-dependent antigens is controlled in part by the level of ICOS costimulation provided by plasma cells, as transgenic B7h overexpression on this cell type resulted in an increase in both the number of responding plasma $\mathrm{B}$ cells and the serum concentration of antigen-specific IgG antibodies.

\section{B7h expression on plasma B cells regulates high affinity} antibody production

The primary immune response to NP-CGG immunization leads to production of low affinity antibody-secreting plasma cells early in the response (peaking at day 7), while the germinal center reaction selects for plasma cells secreting mutated high-affinity antibodies at later time points [32,33]. Having observed an increase in total antigen-specific IgG production in immunized B-B7hTg mice on the $\mathrm{B} 7 \mathrm{~h}^{+/+}$background over non-transgenic controls on day 7 , we wondered whether increased $B 7 \mathrm{~h}$ expression on plasma $\mathrm{B}$ cells in these mice also affected the production of high affinity IgG. We therefore investigated the affinity maturation of anti-NP IgG responses in transgenic and control mice by examining the ratio of high affinity anti-NP IgG (IgG binding $\mathrm{NP}_{1} \mathrm{BSA}$ ) to total anti-NP IgG (IgG binding $\mathrm{NP}_{15} \mathrm{BSA}$ ) by ELISA in sera obtained 21 days after immunization (Figure 5). In comparison to wild-type $\mathrm{B} \mathrm{h}^{+/+}$controls, high-affinity NP-specific IgG responses were defective in $\mathrm{B}^{-1-} \mathrm{h}^{-1}$ mice, consistent with 
A.

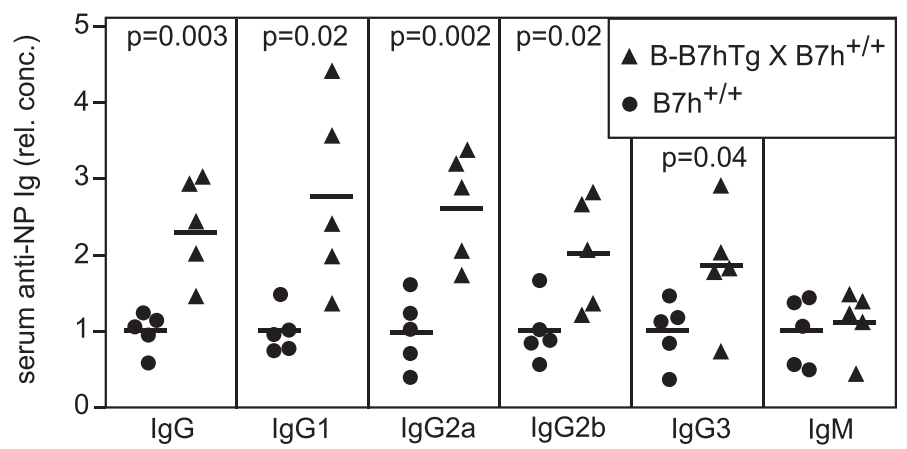

B.

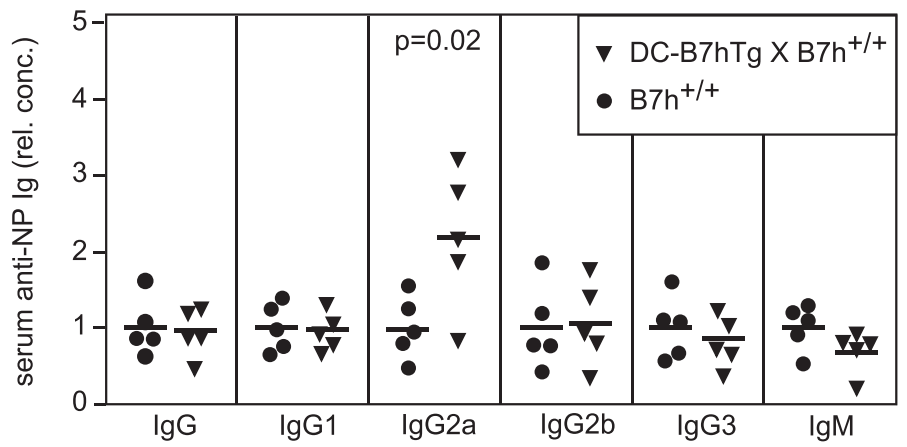

C.

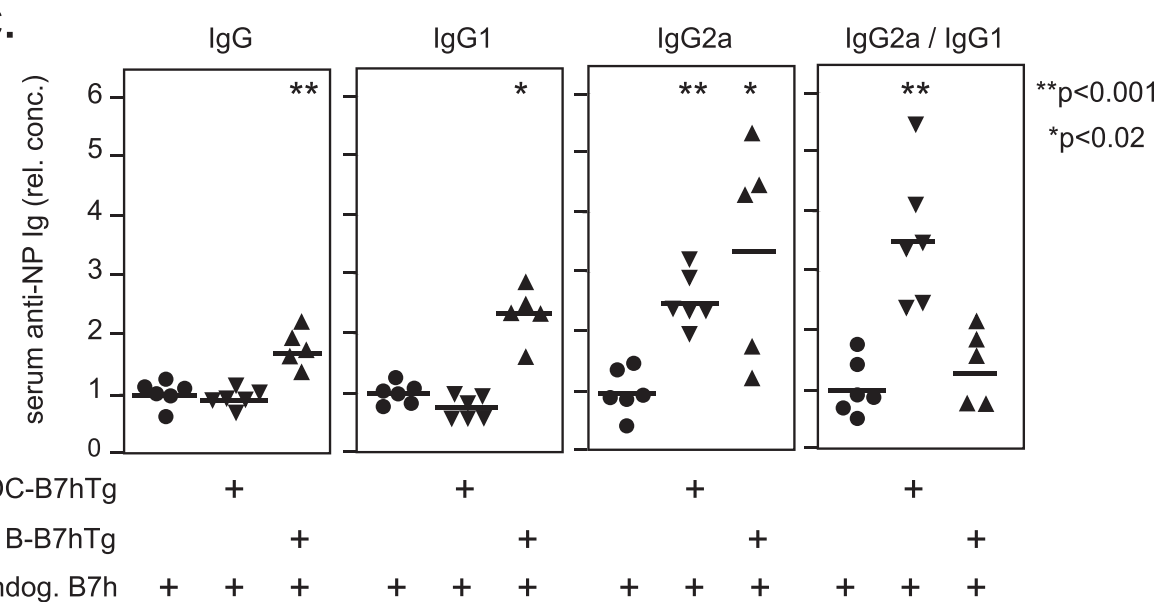

Figure 3 ICOS costimulation mediated by plasma B cells and DCs selectively regulate the magnitude and isotype usage of antibody responses. Transgenic mice on the $B 7 \mathrm{~h}^{+/+}$background and non-transgenic littermate controls were immunized with NP-CGG in alum, and serum antibody responses were analyzed by ELISA. Relative isotype-specific anti-NP serum antibody concentrations at day 7 are shown for B-B7hTg (A) and DC-B7hTg (B) mice, compared with wild-type controls. (C) The relative serum concentrations of anti-NP IgG, IgG1, lgG2a, and the lgG2a/lgG1 ratio are shown at day 14 for transgenic and wild-type mice. Each symbol represents an individual immunized mouse and the mean of each group is indicated by a solid bar. The data were normalized such that control groups have mean value of 1 . Asterisks and $p$ values are shown where statistical significance (Student's $t$ test, $\mathrm{p}<0.05$ ) was detected between transgenic and control groups. The data are representative of at least 3 independent experiments.

previous observations [7]. In contrast, both total and high affinity NP-specific IgG were increased in B-B7hTg mice on the $\mathrm{B}^{+} \mathrm{h}^{+/+}$background, but not in DC-B7hTg mice, when compared with wild-type $\mathrm{B} \mathrm{h}^{+/+}$controls. Thus, enhanced B7h expression on plasma B cells, but not dendritic cells, markedly increased the production of both total and high affinity anti-NP IgG antibodies after immunization. 


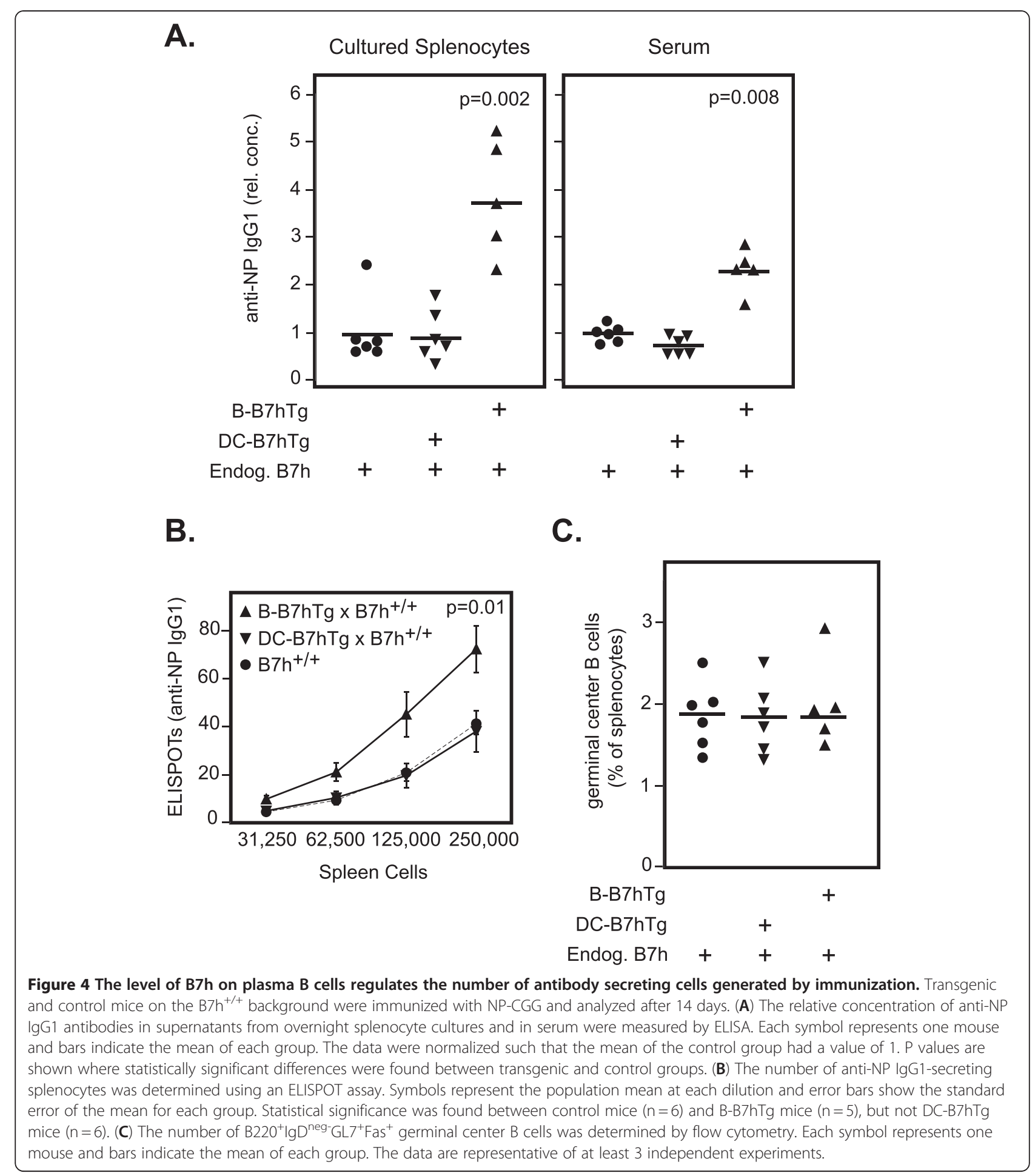

\section{B7h expression on dendritic cells selectively regulates} IgG2a isotype usage

In contrast to our observations in B-B7hTg mice, increased $\mathrm{B} 7 \mathrm{~h}$ expression on dendritic cells in DCB7hTg mice did not affect the magnitude of IgG responses. Parallel immunization experiments with DCB7hTg mice on the $\mathrm{B} \mathrm{h}^{+/+}$background and non- transgenic littermate controls revealed no significant differences in either total IgG or IgM anti-NP responses (Figure 3B). Although overall IgG responses were unaffected, a selective increase in anti-NP IgG2a production was observed in DC-B7hTg mice when compared with wild-type controls, indicating a specific role for ICOS signaling mediated by dendritic cells in promoting 


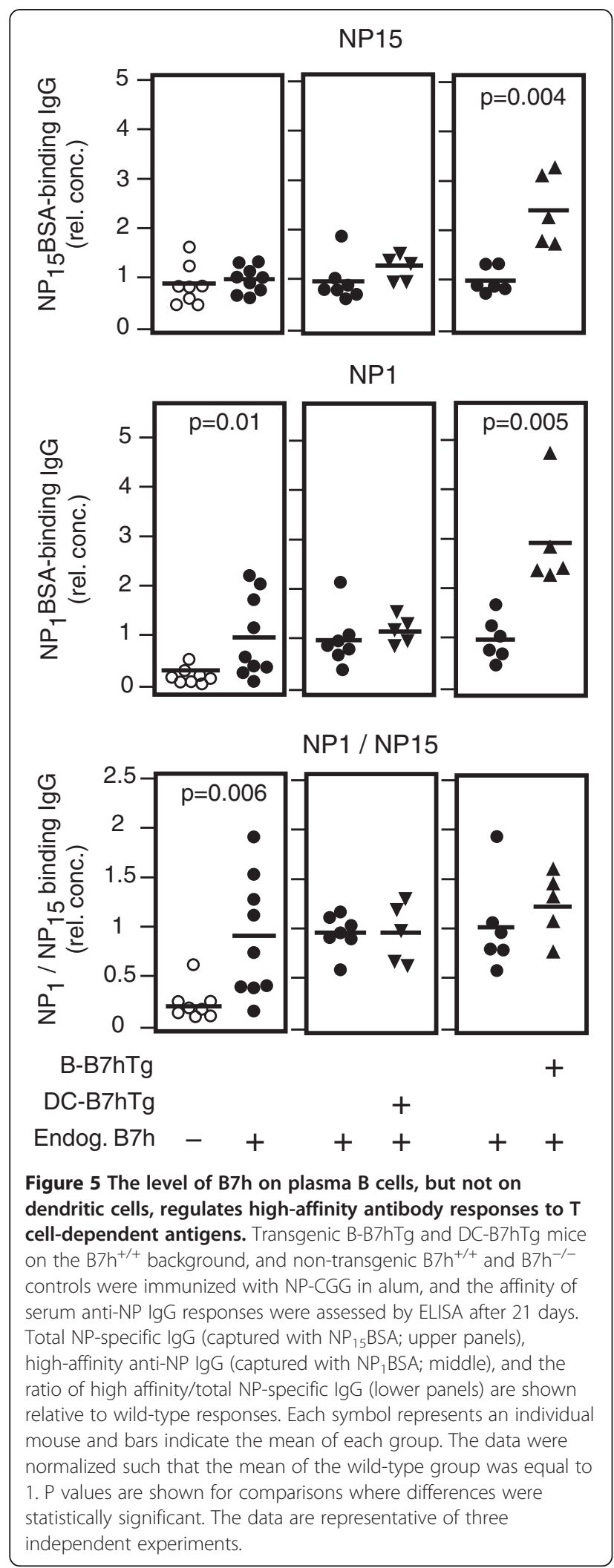

antibody isotype switching to IgG2a. In agreement with these results, the IgG2a/IgG1 ratio of NP-specific serum antibodies was also increased in DC-B7hTg mice on the $\mathrm{B} \mathrm{h}^{+/+}$background compared with wild-type control mice 14 days after immunization (Figure 3C).

\section{B7h expression on dendritic cells contributes to germinal center formation}

Studies of knockout mice have demonstrated the requirement of ICOS signaling for germinal center formation [13-15]. However, the identity of the B7h-expressing cell type(s) that lead to germinal center formation through ligation of ICOS on activated T cells have not been fully defined. To determine whether expression of B7h on DCs or plasma B cells contribute to germinal center formation, we crossed DC-B7hTg and B-B7hTg mice with $\mathrm{B} 7 \mathrm{~h}^{-1-}$ mice, and examined germinal center activity both by immunohistochemical analysis of frozen spleen sections and by flow cytometry 14 days after immunization (Figures 6A, 6B, and Additional file 2: Figure S2). Consistent with prior studies of knockout mice [13-15], PNA+germinal centers were small and rare in immunized $\mathrm{B} 7 \mathrm{~h}^{-/-}$mice, but large and numerous in immunized $\mathrm{B} \mathrm{h}^{+/+}$controls. Restoration of $\mathrm{B} 7 \mathrm{~h}$ expression on dendritic cells (DC-B7hTg), but not on plasma B cells (B-B7hTg), partially rescued germinal center formation in $\mathrm{B}^{-1-} \mathrm{h}^{-1}$ mice, leading to increases in both the size of germinal centers and the number of germinal center B cells, suggesting that ICOS signaling in $\mathrm{T}$ cells mediated by contact with B7h-expressing DCs, but not plasma B cells, contributes to germinal center formation.

Both the total amount of antibody produced and the affinity of the observed antibody responses, as reflected by the ratio of $\mathrm{NP}_{1} \mathrm{BSA}$-binding $/ \mathrm{NP}_{15} \mathrm{BSA}$ binding serum $\operatorname{IgG}$ at day 21 , were dramatically reduced in $\mathrm{B}^{-1 /} \mathrm{h}^{-/}$mice compared with $\mathrm{B} 7 \mathrm{~h}^{+/+}$controls (Figure 6B). While B7h expression on either plasma B cells or DCs in mice on the $\mathrm{B}^{-1-} \mathrm{h}^{-1}$ background was sufficient to restore total IgG responses to wild-type levels, the affinity of the antibody responses in these mice did not reach the level observed in $\mathrm{B} \mathrm{h}^{+/+}$mice. However, partial rescue of germinal center formation in $\mathrm{B}^{-1-} \mathrm{h}^{-1}$ mice by expression of $\mathrm{B} 7 \mathrm{~h}$ on DCs (DC$\mathrm{B} 7 \mathrm{hTg}$ ), but not on plasma B cells (B-B7hTg), was correlated with an increase in the affinity of the antibody response over $\mathrm{B} \mathrm{h}^{-/-}$controls, suggesting that augmentation of germinal center formation by DC-mediated ICOS costimulation lead to increased antibody affinity maturation.

To confirm our observations in transgenic mice on the $\mathrm{B} \mathrm{h}^{+/+}$background, we also assessed antibody isotype usage in transgenic mice on the $\mathrm{B}^{-1-} \mathrm{h}^{-1}$ background by ELISA 14 days after immunization. B7h expression on 


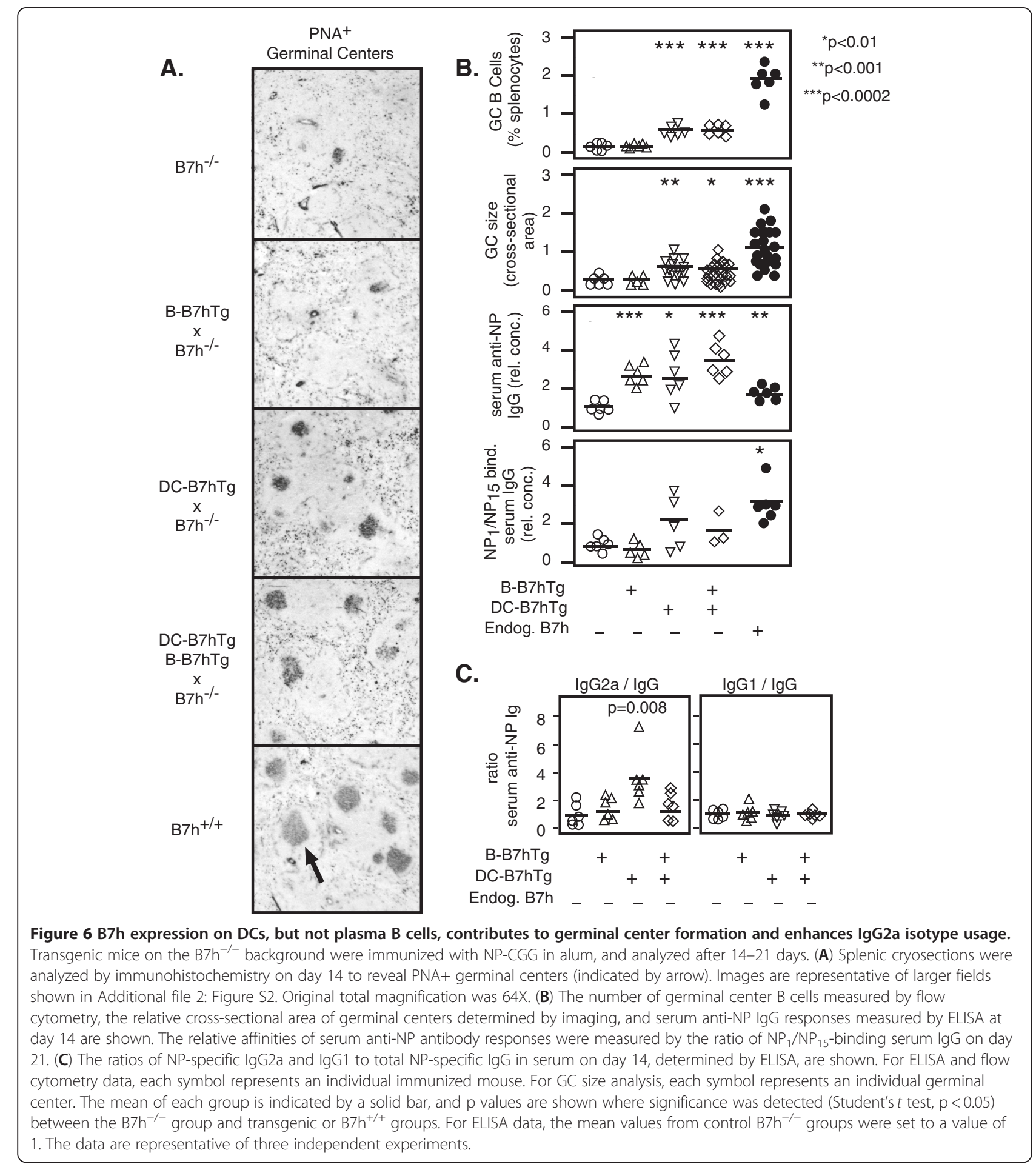

DCs in DC-B7hTg mice on the $\mathrm{B}^{-1-} \mathrm{h}^{-1}$ background again selectively increased isotype switching to $\operatorname{IgG} 2 \mathrm{a}$, reflected by an increase in the NP-specific IgG2a/IgG ratio, but not the $\mathrm{IgG} 1 / \mathrm{IgG}$ ratio, over $\mathrm{B}^{-\mathrm{h}^{-1-}}$ controls (Figure 6C). In contrast, antibody isotype usage was equivalent between B-B7hTg mice on the $\mathrm{B}^{-1} \mathrm{~h}^{-1}$ background and non-transgenic controls. Thus, our results suggest ICOS costimulation mediated by DCs, but not plasma B cells, contributes to germinal center formation and selectively enhances IgG2a isotype usage.

\section{Discussion}

Analyses of both $\mathrm{ICOS}^{-/-}$and $\mathrm{B}^{-/-}$mice have demonstrated the critical requirement of ICOS costimulation 
for normal germinal center formation, antibody isotype switching, affinity maturation, and antibody production in $\mathrm{T}$ cell-dependent antibody responses $[1,7,13,14]$. However, knockout mice exhibit defects at multiple stages of $\mathrm{T}$ cell-dependent antibody responses, ICOS costimulation can have diverse effects on immune responses depending on the context of signaling, and $\mathrm{B} 7 \mathrm{~h}$ is expressed on multiple antigen presenting cell types involved in antibody responses. Thus, studies of knockout mice could not dissect the potential cell typespecific roles of $\mathrm{B} 7 \mathrm{~h}$ expression on antigen presenting cells in $\mathrm{T}$ cell-dependent antibody responses. We have extended previous studies using transgenic mice with lineage-restricted $\mathrm{B} 7 \mathrm{~h}$ expression to define selective roles for ICOS costimulation mediated by DCs and plasma B cells in the context of antibody responses.

Our results demonstrate that endogenous B7h expression is high on naïve and germinal center B cells, but is reduced on activated and plasma $B$ cells, and transgenic induction of $\mathrm{B} 7 \mathrm{~h}$ expression on activated and plasma $\mathrm{B}$ cells in B-B7hTg mice enhances the number of antibodysecreting cells produced in response to $\mathrm{T}$ cell-dependent antigens. The observed expression pattern of the B-B7h transgene may most likely be explained as a result of the use of an immunoglobulin promoter in place of the endogenous B7h promoter sequences to drive transgene expression, as the immunoglobulin promoter is upregulated in plasma B cells, and possibly also by insertion of the transgene at a genomic location that is available for transcription only in activated B cells. The latter possibility could potentially be problematic if the transgene insertion disrupted an endogenous gene that is important for B cell function. Fortunately, we did not observe any defects in B cell function in B-B7hTg mice in vitro or in vivo, leading us to conclude that such a disruption is unlikely to have occurred in this case.

While we observed induction of B7h expression in BB7hTg B cells after BCR cross-linking in vitro, we were unable to specifically identify analogous recently activated $B$ cells in vivo in our system, as the frequency of NP-reactive B cells in naïve mice is very low, and the low affinity of primary naïve B cells for NP precluded direct identification of NP-specific cells by FACS based on NP binding in the first few days after immunization in our hands. Although we could not directly measure B7h expression levels on recently activated B cells in vivo, our in vitro results suggest that the B-B7h transgene may lead to overexpression of B7h on these cells in the first 2-3 days, a time frame in which they interact with cognate activated $\mathrm{T}$ cells in interfolicular regions $[34,35]$. Thus, it is possible that increased ICOS costimulation in $\mathrm{T}$ cells interacting with responding follicular $B$ cells in the first 2-3 days after immunization contributed to the increased antibody responses in B-B7hTg mice. However, it is not clear how ICOS signaling in early cognate B-T interactions could augment the levels of both pre-germinal center low affinity and postgerminal center high affinity antibody production without affecting the number of germinal center B cells.

In addition to expression on in vitro-activated B cells, the B-B7h transgene consistently led to dramatic overexpression of $\mathrm{B} 7 \mathrm{~h}$ on responding plasma $\mathrm{B}$ cells in vivo, and an expansion of these cells in comparison to nontransgenic control mice. The correlation between $\mathrm{B} 7 \mathrm{~h}$ overexpression on plasma cells and cellular expansion of plasma cells in B-B7hTg mice suggests that differentiated plasma B cells make contact with ICOS-expressing activated $\mathrm{T}$ cells, and this interaction regulates the magnitude of antibody responses based in part on the level of B7h expression on B cells, which influences the strength of ICOS signaling in cognate $\mathrm{T}$ cells. This putative plasma cell-T cell interaction could potentially occur between Tfh cells and newly differentiated plasma cells in germinal centers, and/or between activated Th cells and plasma cells that co-localize in peri-arteriolar lymphoid sheaths (PALS) in lymph nodes and spleen [24]. The observed increase in the number of antibody-secreting cells in B-B7hTg mice at day 7 implies that plasma cell-T cell interactions that regulate antibody responses can likely occur outside of germinal centers, as the majority of antibody secreting cells at this early time point are not germinal-center derived [33].

ICOS costimulation in T cells is dynamically regulated on multiple levels. A previous study generated transgenic mice that overexpress ICOS on all T cells [36], and made the counterintuitive finding that antibody and germinal center responses were reduced in ICOS transgenic mice, as a result of the increased clipping of $\mathrm{B} 7 \mathrm{~h}$ from the cell surface of APCs after contact with ICOS [27]. The resulting reduction of $\mathrm{B} 7 \mathrm{~h}$ expression on APCs in ICOS transgenic mice caused a reduction of ICOS costimulation in vivo compared with WT mice, leading to defects in $\mathrm{B}$ cell responses to $\mathrm{T}$ cell-dependent antigens. In addition to ICOS contact, previous in vitro studies have shown that IL4-R and antigen receptor signals reduce cell surface B7h levels on B cells through transcriptional and post-transcriptional mechanisms, while the addition of CD40, TLR7/8 and/or TLR9 signals can limit the extent of B7h downregulation after activation or ICOS contact, causing a relative increase in ICOS co-stimulation in cognate T cells [26,27]. In our B-B7hTg model the B7h transgene was induced on activated $\mathrm{B}$ cells as a result of the transgenic promoter, leading to an increase in cell surface B7h levels on activated B cells, which was most notable in vivo on differentiated plasma B cells. Ultimately this increased cell surface B7h expression led to expansion of plasma cells in vivo, presumably through increased ICOS co-stimulation in cognate T cells. 
These results suggest that $B$ cells regulate the magnitude of antibody responses in part by modulating B7h levels in response to multiple signaling pathways. In this model, physiological settings where endogenous B7h expression on B cells is enhanced or stabilized during antibody responses, such as by CD40 or TLR9 signaling, are predicted to lead to increased classswitched antibody production. Conversely, the results of studies of ICOS transgenic mice suggest that stimuli that lead to an increase in ICOS expression on T cells may counter-intuitively reduce antibody responses through increased clipping of B7h from the cell surface of cognate APCs.

Our results have potential practical implications for the improvement of vaccination strategies, as they demonstrate that ICOS signaling is not only required for many aspects of $\mathrm{T}$ cell-dependent antibody responses, but that the strength of ICOS signaling, which is controlled in part by changing levels of $\mathrm{B} 7 \mathrm{~h}$ on APCs, can modulate antibody responses in the right context. Hence, vaccination strategies that increase ICOS costimulation either directly with ICOS agonists, or indirectly by attempting to stabilize B7h expression on B cells through CD40 or TLR signaling, may be useful to augment the magnitude of vaccine-induced high affinity antibody responses. Conversely, ICOS blockade may be a useful strategy for reducing the expansion of plasma cells secreting pathogenic antibodies in the setting of B cell-mediated autoimmunity $[37,38]$. Interactions between plasma B cells and ICOS+ T cells in the kidneys of lupus patients have been correlated with exaggerated plasma cell generation and pathogenic antibody production [39]. Our data suggest that the level of ICOS signaling in such interactions can regulate the plasma cell response, and blocking ICOS costimulation in this setting may be a useful therapeutic strategy to reduce the production of autoantibodies.

Our results show that overexpression of $\mathrm{B} 7 \mathrm{~h}$ on activated and plasma $B$ cells led to an increase in highaffinity IgG production 21 days after immunization (Figure 5). In this experiment, although a statistically significant difference in high-affinity $\mathrm{NP}_{1}$-binding IgG could be detected between $\mathrm{B} \mathrm{h}^{+/+}$and $\mathrm{B}^{-1 /} \mathrm{h}^{-/}$mice, the difference in total $\mathrm{NP}_{15}$-binding IgG was not significant. This was surprising, as numerous studies have reported defects in class-switched antibody production in $\mathrm{B}^{-1-}$ and $\mathrm{ICOS}^{-/-}$mice or after ICOS blockade in WT mice $[7,14,15,40]$. However, several studies showed a decrease in IgG1, but not IgG2a production, after primary immunization $[7,40]$, suggesting that all isotypes may not be equivalently affected, and the extent of the observed differences vary between studies using different immunogens, adjuvants, and timing of sample collection [14]. In the case of the experiment shown in Figure 5, we may have failed to detect a difference between $\mathrm{B} 7 \mathrm{~h}^{+/+}$and $\mathrm{B} 7 \mathrm{~h}^{-/-}$ responses because we measured all IgG isotypes together, and took blood samples at day 21 for the purpose of measuring affinity maturation, in contrast to previous reports that show differences specifically for the IgG1 isotype, at 7 and 14 days after immunization. In fact, in a similar experiment measuring total $\mathrm{NP}_{15}$-binding IgG at day 14 , we did detect a statistically significant difference between $\mathrm{B} \mathrm{h}^{+/+}$and $\mathrm{B}^{-1 /} \mathrm{h}^{-1}$ animals (Figure $6 \mathrm{~B}$ ), suggesting that while $\mathrm{IgG}$ responses in $\mathrm{B} 7 \mathrm{~h}^{-/-}$mice are initially deficient, at later time points total antigen-specific IgG in immunized $\mathrm{B} 7 \mathrm{~h}^{-/-}$mice may reach wild-type levels, although high-affinity ( $\mathrm{NP}_{1}$-binding) antibody responses were deficient as a result of limited germinal center activity in knockout mice.

Initial studies reported Th1 polarization [16], reduced IL-4 production [15,41], and inhibition of Th2-mediated lung mucosal inflammation [40,42] in the absence of ICOS signaling, suggesting a role for ICOS in Th2 polarization. Additional studies have paradoxically shown amelioration of Th1-mediated allograft rejection [43], EAE [25,44], and diabetes [45] in the absence of ICOS signaling, as well as enhancement of Th1-driven IgG2a production by an activatory B7h-Ig fusion protein [9]. Our results suggest these observations are not contradictory, but rather the outcome of ICOS signaling in activated T cells is highly dependent on the context of B7h-ICOS interactions, as B7h expressed on dendritic cells, but not plasma B cells, can specifically enhance Th1-driven IgG2a responses, while B7h expression on plasma B cells increases IgG production of all isotypes. This may in part reflect the fact that responding DCs and plasma B cells can localize to separate micro-environments, and potentially interact with $\mathrm{CD} 4+\mathrm{T}$ cells in different states of differentiation that regulate distinct aspects of antibody responses.

In addition to the effect on antibody isotype switching, we show that B7h expression on dendritic cells also contributes to germinal center formation, which leads to antibody affinity maturation. However, the number of responding germinal center $\mathrm{B}$ cells in mice that only express B7h on DCs (DC-B7hTg $\mathrm{x}$ $\mathrm{B} \mathrm{h}^{-/-}$) was reduced in comparison to wild-type $\mathrm{B} 7 \mathrm{~h}^{+/+}$ mice (Figure $5 \mathrm{~b}$ ), suggesting that additional ICOS costimulation mediated by other cell types is necessary for optimal germinal center responses and antibody affinity maturation. Since ICOS expression is high on Tfh cells in germinal centers and endogenous B7h expression is high on germinal center B cells, it is likely that germinal center B cell-mediated ICOS signaling in Tfh cells also contributes to the size and dynamics of germinal centers and the extent of antibody affinity maturation in wild-type mice. 


\section{Conclusions}

In summary, ICOS costimulation mediated by plasma B cells and dendritic cells have distinct functions in T celldependent antibody responses. While ICOS signaling in $\mathrm{T}$ cells mediated by B7h-expressing DCs contributes to germinal center formation and can affect antibody isotype usage, the B7h expression level on plasma B cells regulates the overall magnitude of antibody responses to T cell-dependent antigens without affecting antibody isotype usage or the number of germinal center B cells. The latter result suggests a control point that may be useful for enhancement of vaccine-induced antibody responses, or reduction of pathogenic antibody responses, through modulation of ICOS signaling.

\section{Methods}

\section{Transgenic mice}

All work involving animals was performed in accordance with the NIH Office of Laboratory Animal Welfare guidelines and was approved by the UC Berkeley Institutional Animal Care and Use Committee.

The construct driving B7h expression in B-B7hTg mice was created by modifying an existing vector that utilizes an immunoglobulin $\mathrm{V}_{\mathrm{H}}$ promoter and enhancer for cDNA expression in B cells [29], in which transcription is driven by a $0.9 \mathrm{~kb} \mathrm{XbaI}$ fragment containing the intronic $\mathrm{E} \mu$ enhancer and a $1.4 \mathrm{~kb}$ fragment of the $\mathrm{V}_{\mathrm{H}}$ 17.2.25 promoter ending at a Sall cloning site at position +38 , upstream of the Kozak ATG sequence at +47 [46]. A SalI-NotI blunted B7h-GFP cDNA insert, encoding for a previously described B7h-GFP fusion protein [5], where the $\mathrm{N}$ terminus of GFP was fused to the $\mathrm{C}$ terminal end of the cytoplasmic tail of full-length $\mathrm{B} 7 \mathrm{~h}$, was sub-cloned into the Sall site of the vector, which was additionally modified to replace the SV40 splice and polyA sequences with a BamHI-NotI insert containing the human growth hormone $(\mathrm{hGH})$ minigene from the p1017-lck expression vector plasmid [47]. A $6.9 \mathrm{~kb}$ NotI insert lacking plasmid vector sequences was microinjected into (CBA X B6) $F_{1}$ embryos. The B-B7hTg line utilized in these studies was subsequently backcrossed to B6 mice for at least 10 generations.

The construct driving B7h expression in DC-B7hTg mice was created by modifying an existing transgenic vector designed for cDNA expression in DCs driven by the $\mathrm{CD} 11 \mathrm{c}$ promoter upstream of the rat $\beta$-globin splice site and polyA signal sequence [28]. A blunted $2.5 \mathrm{~kb}$ B7hIRES-GFP cDNA insert, excised from an MSCV-IRESGFP retroviral vector $[27,48]$ expressing the $\mathrm{B} 7 \mathrm{~h}$ cDNA [5], was then sub-cloned into a PmeI site that was introduced into the EcoRI cloning site of the vector by annealing overlapping primers 5- AATTGTTTAAAGCCGG$3^{\prime}$ and $5^{\prime}$-ATTCCGGGTTTAAAC-3' to the EcoRIdigested vector. A $9 \mathrm{~kb}$ NotI-XhoI insert lacking plasmid vector sequences was then microinjected into B6 embryos. The DC-B7hTg line reported here was selected for high B7h expression on $\mathrm{CD} 11 \mathrm{c}^{+}$cells. Transgenic lines were crossed onto $\mathrm{B} \mathrm{h}^{-1-}$ mice on the $\mathrm{C} 57 \mathrm{Bl6} / \mathrm{J}$ background, a generous gift of Dr. Tak Mak [7], and were maintained on the C57Bl6/J background.

\section{Immunization}

NP-OsU (Biosearch Technologies) was conjugated to chicken gamma globulin (CGG; Jackson Immunoresearch) or bovine serum albumin (BSA; Sigma) to form NP-CGG or NP-BSA at different conjugation ratios that were confirmed by spectroscopy. Age-matched groups of mice were immunized intraperitoneally in the lower right quadrant with $100 \mu \mathrm{g} \mathrm{NP}_{10} \mathrm{CGG}$ precipitated in alum, in a final volume of $100 \mu \mathrm{L}$ phosphate-buffered saline (PBS). Levels of NP-specific antibodies in sera were detected using ELISA plates (Costar) coated with $5 \mu \mathrm{g} / \mathrm{mL} \mathrm{NP}{ }_{15} \mathrm{BSA}$ or $\mathrm{NP}_{1} \mathrm{BSA}$ in PBS overnight at $4^{\circ} \mathrm{C}$, and isotype-specific HRP-conjugated anti-mouse IgG or IgG1 (Southern Biotech), or biotinylated anti-mouse IgG2a, IgG2b, IgG3 or IgM (Pharmingen) detection reagents. Plates were developed with streptavidinconjugated HRP and ABTS substrate (Pharmingen), and absorbance at $405 \mathrm{~nm}$ of a two-fold dilution series in the linear range was used to calculate relative amounts of antiNP antibodies. ELISPOT analysis of antibody producing cells was conducted using MultiScreen-IP plates (Millipore) coated with $50 \mu \mathrm{g} / \mathrm{mL} \mathrm{NP}_{15}$ BSA. Purified splenocytes were serially diluted in duplicate onto blocked washed plates in lymphocyte media and cultured overnight at $37^{\circ} \mathrm{C}$. NP-specific spots were detected with an HRP-conjugated goat anti-mouse IgG1 antibody (Southern Biotech), developed using the AEC chromagen kit (Sigma), and ELISPOTs were counted using a dissecting microscope.

\section{Flow cytometry and cells}

Immature dendritic cells were derived by isolating bone marrow from the long bones of the legs and culturing in IMDM containing 10\% FBS, $1 \%$ Pen/Strep, and $500 \mathrm{ng} / \mathrm{mL}$ GM-CSF (R\&D Systems) for 7 days. Splenic dendritic cells were enriched in some experiments by injecting mice subcutaneously with an FLT3L-secreting B16 tumor cell line 14-21 days before analysis. Dissected spleens were injected with $400 \mathrm{U} / \mathrm{mL}$ collagenase in PBS to disaggregate splenocytes, and dead cells were removed by density gradient centrifugation prior to isolation of DCs with anti-CD11c microspheres (Miltenyi Biotec). Dendridic cells were activated in some experiments by culture for 16 hours in the presence of $1 \mu \mathrm{g} / \mathrm{mL}$ LPS (Sigma). B and T cells were purified from mice as described previously [26] and activated by culture in 96 -well plates at $10 \times 10^{6}$ cells/ 
$\mathrm{mL}$ for $16-72$ hours in the presence of $5 \mu \mathrm{g} / \mathrm{mL}$ goat anti-mouse-IgM $\mathrm{F}(\mathrm{ab})_{2}$ (Jackson Immunoresearch), $250 \mathrm{~nm}$ PMA (Sigma) and $2 \mu \mathrm{M}$ Ionomycin (Sigma), $10 \mu \mathrm{g} / \mathrm{mL}$ LPS (Sigma), $5 \mu \mathrm{g} / \mathrm{mL}$ CpG oligonucleotide 1826 (5'-TCCATGACGTTCCTGACGTT-3'), or $5 \mathrm{ng} / \mathrm{mL}$ IL-4 (R\&D Systems).

Splenocyte suspensions or purified cells were stained for flow cytometric analysis as described [27] using the following reagents: IgD-FITC (eBioscience), B220PETexasRed (Pharmingen), Fas-PECy7 (Pharmingen), syndecan-1-APC (Pharmingen), CDllc-PE (Caltag), CD11c-PECy7 (Pharmingen), B7.2-PE (Pharmingen), purified rat IgM anti-GL7 (eBioscience) followed by anti-rat IgM-PE secondary (eBioscience), and 22D7 hamster anti-mouse B7h [13] followed by streptavidinPE (eBioscience) or streptavidin-PECy5 (Pharmingen). For cell surface B7h analysis, splenocytes were cultured for 2 hours at $37^{\circ} \mathrm{C}$ in lymphocyte media and blocked with $220 \mu \mathrm{g} / \mathrm{mL}$ Syrian hamster gamma globulin (Jackson ImmunoResearch). Germinal center B cells were gated as $\mathrm{B}_{22} 20^{+} \mathrm{IgD}^{\text {neg }} \mathrm{GL}^{+} \mathrm{Fas}^{\text {hi }}$, plasma cells were $\operatorname{IgD}^{\text {neg- }}$ Syndecan ${ }^{+} \mathrm{B} 220^{\mathrm{lo}}$, naïve $\mathrm{B}$ cells were $\mathrm{B} 220^{+} \mathrm{IgD}^{+}$, and dendritic cells were $C D 19^{\text {neg }} C D 11 c^{+}$.

\section{Immunohistochemistry}

Spleens from immunized mice were snap frozen in OCT, and glass slides with microtome sliced issues sections cut to 5-7 $\mu \mathrm{m}$ were stained with biotinylated peanut agglutinin (PNA) in PBS. PNA+ germinal centers were revealed using an $\mathrm{ABC}$ Elite staining kit with $\mathrm{DAB}$ substrate (Vector labs). Slides were imaged on a Zeiss NeoLumar stereomicroscope using a $0.8 \mathrm{x}, 80 \mathrm{~mm}$ objective at $64 \mathrm{X}$ total magnification. Images were acquired with a MicroPublisher 3.3 Qimaging camera and QImaging software; contrast of final images was adjusted uniformly to all images using Adobe Photoshop.

\section{Statistical analysis}

Statistical significance between groups of mice was evaluated using Student's $t$ test (one-tailed, two sample, unequal variance). All analyses returning a $\mathrm{p}$ value $<0.05$ are labeled. Analyses where no $\mathrm{p}$ value is shown returned $\mathrm{p}>0.05$.

\section{Additional files}

Additional file 1: Figure S1. Normal lymphocyte populations in resting B7hTg mice. Splenic lymphocyte populations were assessed in resting BB7hTg and DC-B7hTg animals on the B7h ${ }^{+/+}$background by flow cytometry. The number of lineage marker positive cells is plotted as a percentage of total splenocytes, with representative gating shown on the left. Each symbol represents an individual animal, with the mean of each group represented by a solid bar.

Additional file 2: Figure S2. Defective germinal center formation is restored by expression of $B 7 h$ on $C D 11 c+$ dendritic cells, but not on plasma B cells. Splenic cryosections from immunized mice at day 14 were analyzed by immunohistochemistry to detect PNA+ germinal centers. Images correspond to data presented in Figure 5. Original magnification was $64 x$.

\section{Competing interests}

The authors declare that they have no competing interests.

\section{Authors' contributions}

SB generated the DNA construct used to create DC-B7hTg mice. LL generated and initially characterized the B-B7hTg mouse line. $K L$ generated the DC-B7hTg mouse line, performed all experiments with results shown, and drafted the manuscript. BS contributed to the study design and supervised the studies. All authors read and approved the final manuscript.

\section{Acknowledgements}

This work was supported by funding from the Sandler Program for Asthma Research. We gratefully acknowledge Chulho Kang, who performed the embryo microinjection of DNA constructs to generate the transgenic mice used in this study.

Received: 28 February 2012 Accepted: 22 May 2012

Published: 11 June 2012

\section{References}

1. Dong C, Juedes AE, Temann UA, Shresta S, Allison JP, Ruddle NH, Flavell RA: ICOS co-stimulatory receptor is essential for T-cell activation and function. Nature 2001, 409:97-101.

2. Hutloff A, Dittrich AM, Beier KC, Eljaschewitsch B, Kraft R, Anagnostopoulos I, Kroczek RA: ICOS is an inducible T-cell co-stimulator structurally and functionally related to CD28. Nature 1999, 397:263-266.

3. Greenwald RJ, Freeman GJ, Sharpe AH: The B7 family revisited. Annu Rev Immunol 2005, 23:515-548.

4. Carreno BM, Collins M: The B7 family of ligands and its receptors: new pathways for costimulation and inhibition of immune responses. Annu Rev Immunol 2002, 20:29-53.

5. Swallow MM, Wallin JJ, Sha WC: B7h, a novel costimulatory homolog of B7.1 and B7.2, is induced by TNFalpha. Immunity 1999, 11:423-432.

6. Brodie D, Collins AV, laboni A, Fennelly JA, Sparks LM, Xu XN, van der Merwe PA, Davis SJ: LICOS, a primordial costimulatory ligand? Curr Biol 2000, 10:333-336.

7. Mak TW, Shahinian A, Yoshinaga SK, Wakeham A, Boucher L-M, Pintilie M, Duncan G, Gajewska BU, Gronski M, Eriksson U, Odermatt B, Ho A, Bouchard D, Whorisky JS, Jordana M, Ohashi PS, Pawson T, Bladt F, Tafuri A: Costimulation through the inducible costimulator ligand is essential for both $\mathrm{T}$ helper and $\mathrm{B}$ cell functions in T cell-dependent B cell responses. Nat Immunol 2003, 4:765-772.

8. $\quad$ Ling V, Wu PW, Finnerty HF, Bean KM, Spaulding V, Fouser LA, Leonard JP, Hunter SE, Zollner R, Thomas JL, Miyashiro JS, Jacobs KA, Collins M: Cutting edge: identification of GL50, a novel B7-like protein that functionally binds to ICOS receptor. J Immunol 2000, 164:1653-1657.

9. Yoshinaga SK, Whoriskey JS, Khare SD, Sarmiento U, Guo J, Horan T, Shih G, Zhang M, Coccia MA, Kohno T, Tafuri-Bladt A, Brankow D, Campbell P, Chang D, Chiu L, Dai T, Duncan G, Elliott GS, Hui A, McCabe SM, Scully S, Shahinian A, Shaklee CL, Van G, Mak TW, Senaldi G: T-cell co-stimulation through B7RP-1 and ICOS. Nature 1999, 402:827-832.

10. Wang S, Zhu G, Chapoval Al, Dong H, Tamada K, Ni J, Chen L: Costimulation of T cells by $\mathrm{B} 7-\mathrm{H} 2$, a B7-like molecule that binds ICOS. Blood 2000, 96:2808-2813.

11. Aicher A, Hayden-Ledbetter M, Brady WA, Pezzutto A, Richter G, Magaletti D, Buckwalter S, Ledbetter JA, Clark EA: Characterization of human inducible costimulator ligand expression and function. J Immunol 2000, 164:4689-4696.

12. Yoshinaga SK, Zhang M, Pistillo J, Horan T, Khare SD, Miner K, Sonnenberg M, Boone T, Brankow D, Dai T, Delaney J, Han H, Hui A, Kohno T, Manoukian R, Whoriskey JS, Coccia MA: Characterization of a new human B7-related protein: B7RP-1 is the ligand to the co-stimulatory protein ICOS. Int Immunol 2000, 12:1439-1447. 
13. Dong C, Temann UA, Flavell RA: Cutting edge: critical role of inducible costimulator in germinal center reactions. J Immunol 2001, 166:3659-3662.

14. McAdam AJ, Greenwald RJ, Levin MA, Chernova T, Malenkovich N, Ling V, Freeman GJ, Sharpe AH: ICOS is critical for CD40-mediated antibody class switching. Nature 2001, 409:102-105.

15. Tafuri A, Shahinian A, Bladt F, Yoshinaga SK, Jordana M, Wakeham A, Boucher LM, Bouchard D, Chan VS, Duncan G, Odermatt B, Ho A, Itie A, Horan T, Whoriskey JS, Pawson T, Penninger JM, Ohashi PS, Mak TW: ICOS is essential for effective T-helper-cell responses. Nature 2001, 409:105-109.

16. McAdam AJ, Chang TT, Lumelsky AE, Greenfield EA, Boussiotis VA, Duke-Cohan JS, Chernova T, Malenkovich N, Jabs C, Kuchroo VK, Ling V, Collins M, Sharpe AH, Freeman GJ: Mouse inducible costimulatory molecule (ICOS) expression is enhanced by CD28 costimulation and regulates differentiation of CD4+ T cells. J Immunol 2000, 165:5035-5040.

17. Nurieva RI, Duong J, Kishikawa H, Dianzani U, Rojo JM, Ho IC, Flavell RA, Dong C: Transcriptional regulation of th2 differentiation by inducible costimulator. Immunity 2003, 18:801-811.

18. Greenwald RJ, McAdam AJ, Van der Woude D, Satoskar AR, Sharpe AH: Cutting edge: inducible costimulator protein regulates both Th1 and Th2 responses to cutaneous leishmaniasis. J Immunol 2002, 168:991-995.

19. Khayyamian S, Hutloff A, Büchner K, Gräfe M, Henn V, Kroczek RA, Mages HW: ICOS-ligand, expressed on human endothelial cells, costimulates Th1 and Th2 cytokine secretion by memory CD4+ T cells. Proc Natl Acad Sci U S A 2002, 99:6198-6203.

20. Bonhagen K, Liesenfeld O, Stadecker MJ, Hutloff A, Erb K, Coyle AJ, Lipp M, Kroczek RA, Kamradt T: ICOS + Th cells produce distinct cytokines in different mucosal immune responses. Eur J Immunol 2003, 33:392-401.

21. Goenka R, Barnett LG, Silver JS, O apos Neill PJ, Hunter CA, Cancro MP, Laufer TM: Cutting edge: dendritic cell-restricted antigen presentation initiates the follicular helper T cell program but cannot complete ultimate effector differentiation. J Immunol 2011, 187:1091-1095.

22. Allen CDC, Okada T, Cyster JG: Germinal-center organization and cellular dynamics. Immunity 2007, 27:190-202.

23. Allen CDC, Okada T, Tang HL, Cyster JG: Imaging of germinal center selection events during affinity maturation. Science 2007, 315:528-531.

24. Van den Eertwegh AJ, Noelle RJ, Roy M, Shepherd DM, Aruffo A, Ledbetter JA, Boersma WJ, Claassen E: In vivo CD40-gp39 interactions are essential for thymus-dependent humoral immunity. I. In vivo expression of CD40 ligand, cytokines, and antibody production delineates sites of cognate T-B cell interactions. J Exp Med 1993, 178:1555-1565.

25. Rottman JB, Smith T, Tonra JR, Ganley K, Bloom T, Silva R, Pierce B, Gutierrez-Ramos JC, Ozkaynak E, Coyle AJ: The costimulatory molecule ICOS plays an important role in the immunopathogenesis of EAE. Nat Immunol 2001, 2:605-611.

26. Liang L, Porter EM, Sha WC: Constitutive expression of the B7h ligand for inducible costimulator on naive B cells is extinguished after activation by distinct $B$ cell receptor and interleukin 4 receptor-mediated pathways and can be rescued by CD40 signaling. J Exp Med 2002, 196:97-108.

27. Logue EC, Bakkour S, Murphy MM, Nolla H, Sha WC: ICOS-induced B7h shedding on B cells is inhibited by TLR7/8 and TLR9. J Immuno/ 2006, 177:2356-2364.

28. Riedinger M, Karjalainen $\mathrm{K}$, Brocker T: Targeted expression of MHC class II genes to dendritic cells in vivo. Immunol Lett 1997, 57:155-158.

29. Azuma T, Motoyama N, Fields LE, Loh DY: Mutations of the chloramphenicol acetyl transferase transgene driven by the immunoglobulin promoter and intron enhancer. Int Immunol 1993, 5:121-130.

30. Fournier S, Rathmell JC, Goodnow CC, Allison JP: T cell-mediated elimination of B7.2 transgenic B cells. Immunity 1997, 6:327-339.

31. MacLennan IC, Liu YJ, Johnson GD: Maturation and dispersal of B-cell clones during T cell-dependent antibody responses. Immunol Rev 1992, 126:143-161.

32. Takahashi Y, Dutta PR, Cerasoli DM, Kelsoe G: In situ studies of the primary immune response to (4-hydroxy-3-nitrophenyl)acetyl V. Affinity maturation develops in two stages of clonal selection. J Exp Med 1998 187:885-895.

33. Jacob J, Kassir R, Kelsoe G: In situ studies of the primary immune response to (4-hydroxy-3-nitrophenyl)acetyl. I. The architecture and dynamics of responding cell populations. J Exp Med 1991, 173:1165-1175.
34. Okada T, Miller MJ, Parker I, Krummel MF, Neighbors M, Hartley SB, O'Garra A, Cahalan MD, Cyster JG: Antigen-engaged B cells undergo chemotaxis toward the $\mathrm{T}$ zone and form motile conjugates with helper T cells. PLoS Biol 2005, 3:e150.

35. Okada T, Cyster JG: B cell migration and interactions in the early phase of antibody responses. Curr Opin Immunol 2006, 18:278-285.

36. Watanabe M, Takagi Y, Kotani M, Hara Y, Inamine A, Hayashi K, Ogawa S, Takeda K, Tanabe K, Abe R: Down-regulation of ICOS ligand by interaction with ICOS functions as a regulatory mechanism for immune responses. $\mathrm{J}$ Immunol 2008, 180:5222-5234.

37. Odegard JM, Marks BR, DiPlacido LD, Poholek AC, Kono DH, Dong C, Flavell RA, Craft J: ICOS-dependent extrafollicular helper T cells elicit IgG production via IL-21 in systemic autoimmunity. J Exp Med 2008, 205:2873-2886.

38. Davidson A, Aranow C: Lupus nephritis: lessons from murine models. Nat Rev Rheumatol 2010, 6:13-20.

39. Hutloff A, Büchner K, Reiter K, Baelde HJ, Odendahl M, Jacobi A, Dörner T, Kroczek RA: Involvement of inducible costimulator in the exaggerated memory $B$ cell and plasma cell generation in systemic lupus erythematosus. Arthritis Rheum 2004, 50:3211-3220.

40. Coyle AJ, Lehar S, Lloyd C, Tian J, Delaney T, Manning S, Nguyen T, Burwell T, Schneider H, Gonzalo JA, Gosselin M, Owen LR, Rudd CE, Gutierrez-Ramos JC: The CD28-related molecule ICOS is required for effective T cell-dependent immune responses. Immunity 2000, 13:95-105.

41. Nurieva RI, Mai XM, Forbush K, Bevan MJ, Dong C: B7h is required for T cell activation, differentiation, and effector function. Proc Natl Acad Sci U S A 2003, 100:14163-14168.

42. Gonzalo JA, Tian J, Delaney T, Corcoran J, Rottman JB, Lora J, Al-garawi A, Kroczek R, Gutierrez-Ramos JC, Coyle AJ: ICOS is critical for T helper cell-mediated lung mucosal inflammatory responses. Nat Immunol 2001, 2:597-604.

43. Ozkaynak E, Gao W, Shemmeri N, Wang C, Gutierrez-Ramos JC, Amaral J, Qin S, Rottman JB, Coyle AJ, Hancock WW: Importance of ICOS-B7RP-1 costimulation in acute and chronic allograft rejection. Nat Immunol 2001, 2:591-596.

44. Sporici RA, Beswick RL, von Allmen C, Rumbley CA, Hayden-Ledbetter M, Ledbetter JA, Perrin PJ: ICOS ligand costimulation is required for T-cell encephalitogenicity. Clin Immunol 2001, 100:277-288.

45. Hawiger D, Tran E, Du W, Booth CJ, Wen L, Dong C, Flavell RA: ICOS mediates the development of insulin-dependent diabetes mellitus in nonobese diabetic mice. J Immunol 2008, 180:3140-3147.

46. Grosschedl R, Baltimore D: Cell-type specificity of immunoglobulin gene expression is regulated by at least three DNA sequence elements. Cell 1985, 41:885-897.

47. Lewis DB, Yu CC, Forbush KA, Carpenter J, Sato TA, Grossman A, Liggitt DH, Perlmutter RM: Interleukin 4 expressed in situ selectively alters thymocyte development. J Exp Med 1991, 173:89-100.

48. Ranganath S, Ouyang W, Bhattarcharya D, Sha WC, Grupe A, Peltz G, Murphy KM: GATA-3-dependent enhancer activity in IL-4 gene regulation. J Immunol 1998, 161:3822-3826.

doi:10.1186/1471-2172-13-29

Cite this article as: Larimore et al:: B7h-expressing dendritic cells and plasma B cells mediate distinct outcomes of ICOS costimulation in T cell-dependent antibody responses. BMC Immunology 2012 13:29.

\section{Submit your next manuscript to BioMed Central and take full advantage of:}

- Convenient online submission

- Thorough peer review

- No space constraints or color figure charges

- Immediate publication on acceptance

- Inclusion in PubMed, CAS, Scopus and Google Scholar

- Research which is freely available for redistribution 